\title{
Impact of Land Acquisition on the Sustainable Livelihoods in Ninh Thuan Province, Vietnam
}

\author{
Ngo Thi Phuong Thao
}

\begin{abstract}
The concept of sustainable livelihood is an attempt to go beyond the conventional definitions and approaches to poverty eradication. These had been found to be too narrow because they focused only on certain aspects or manifestations of poverty, such as low income, or did not consider other vital aspects of poverty such as vulnerability and social exclusion. It is now recognized that more attention must be paid to the various factors and processes which either constrain or enhance poor people's ability to make a living in an economically, ecologically, and socially sustainable manner. Construction of nuclear power plants in Vietnam is in the first step of implementing and will be allocated in Thuan Nam and Ninh Hai districts, Ninh Thuan province, an agricultural and poor province in Vietnam. This requires a large area of land mobilized, thus a part of popupation living in the project area has to move far away. Besides the positive effects of this project, there are significantly negative impacts on the people living in the project areas and nearby, and their livelihoods are seriously affected. This paper aims at assessing the impact of the nuclear power plants construction on the livelihoods of people in two districts in Ninh Thuan province, in order to have mechanisms and policies to support reasonably and effectively, contributing to stabilize people's lives and local development.
\end{abstract}

\section{Keywords}

Sustainable livelihood, land acquisition, compensation, resettlement

The National Assembly passed Resolution No. 41/2009/QH12 of November 25, 2009 on the policy of building a nuclear power plant Ninh Thuan 1 located at Phuoc Dinh commune, Thuan Nam district and nuclear power plant Ninh Thuan 2 located at Vinh Hai commune, Ninh Hai district, Ninh Thuan province. These are large-scale projects, with strategic significance, serving socio-economic development of the country entering the completion phase of industrialization and modernization and becoming an industrial country.

Thuan Nam and Ninh Hai is two agricultural district of Ninh Thuan province, people live mainly on agricultural production activities such as cultivation (crop mainstream grapes, onions, garlic...) and aquaculture. The people's lives in these districts still have a lot of difficulties. Nuclear power plants construction projects are being implemented at initial steps. Accordingly, a large area of land and labor for agricultural production and the development of economic and social activities have been mobilized. In particular, a part of population living in this area has to move far away from power projects; an infrastructure division will be broken, their lives will be affected (Nguyen 2013).

aThe National Economics University, Vietnam

\section{Correspondent Author:}

Ngo Thi Phuong Thao, The National Economic University, 207 Giai Phong Road, Hai Ba Trung District, Hanoi, Vietnam 
The paper focuses on the analysis of the impact of the nuclear power plants construction on the sustainable livelihoods and proposes mechanisms and specific policies to ensure sustainable livelihoods for people in Ninh Thuan province. The data are based on actual survey of the project "Specific policies and mechanism to support to Thuan Nam and Ninh Hai, Ninh Thuan where building nuclear power plants” of the advisory group for the Ninh Thuan province, in which the author of this paper is a member.

\section{METHODS}

Qualitative and quantitative analysis methods with primary and secondary data collected from the reality surveys were used to analyse and assess the solutions for ensuring sustainable livelihood for people when lands are acquired for building nuclear power plants in Ninh Thuan, Vietnam. In addition, the PRA (Participated Rural Appraisal) method and reality survey were added to analyse the impact of building the nuclear power plants on the people living on the affected areas and the policies and special mechanisms supporting them to live on.

\section{RESULTS}

The Impact of Land Acquisition to Build Nuclear Power Plants on the Sustainable Livelihoods of the People in Ninh Hai and Thuan Nam District, Ninh Thuan Province

Development of nuclear power plants is inevitable in the sustainable development of every country in the world. Because nuclear power is cheaper than electricity produced from other sources of fuels; Nuclear power energy is environmentally friendly, with emissions of $\mathrm{CO}_{2}$ and greenhouse gases being lowest in the electric energy; Nuclear power has high requirements on the safety of construction and operation. In particular, nuclear power is the solution to meet the rising electricity demand as Vietnam entered the stage of accelerated industrialization and modernization (Vietnam Electricity Department 2012).

In Vietnam, the place chosen to build nuclear power plants is Vinh Truong village, Phuoc Dinh commune, Thuan Nam district, Ninh Thuan with a total land area of 540 hectares including isolated areas. Another one is located in Thai An village, Vinh Hai commune, Ninh Hai district with land area of 550 hectares including isolated areas. The construction of nuclear power plants in two districts besides the positive impact, also has a negative impact on the lives of people living there. A lot of problems arise such as loss of productive land, unemployment, shrinking production, difficulty in consumption of agricultural products, and loss of income. Most of the comments agreed that loss of productive land is strongly effective on the sustainable livelihoods for the people living there.

Considering in the range of two districts generally. The land quality and condition in these districts is very good and suitable for agricultural production with high economic value products such as grapes, onions, garlic, and other agricultural products. Agricultural land is an important source of livelihood for resettlers and agricultural producers. A large of agricultural land area is acquired for building the nuclear power plants affecting seriously on the people's living. The decline in the production land area and quality results in the decline in the income from agricultural production. According to the data surveyed, the average income from agricultural production of the households in the area, mainly from growing onions and garlic is 13 million/acre/season; two seasons per year, with production land area average of 3-4 acres/household. Therefore, total income of a household is $80-100$ million/year. After resettlement, land production fell only 1.5-2 acres/household, their income will decrease by more than a half, to about $30-40$ million/year/household (as shown in Table 1). 
Regarding aquaculture and fishing: Thuan Nam and Ninh Hai are coastal districts, so aquaculture and fishing are quite developed. In Thuan Nam district, exploiting force developed rapidly, the scale vessels growing, gradually expanding offshore fishing. Currently, Ninh Thuan province has implementing the project, upgrading $\mathrm{Ca} \mathrm{Na}$ port scale type to 1,200 ships anchored out with total investment of 36 billion dong. Fishing is increasingly developed in two districts, brings high revenues, and is relatively stable for people living in two districts. Thus, fishing is an activity quite sustainable for Ninh Hai and Thuan Nam. However, the construction of nuclear power plants, requiring far from $30 \mathrm{~km}$, will narrow the fishing grounds in the two districts, the livelihoods of fishermen will be affected seriously.

On the other hand, the non-agricultural production sector, such as industry, handicrafts, construction, and services will be also affected. Therefore, special mechanism and policy are actually needed to create more jobs and increase income for people in two districts.

For people whose land is directly acquired. The impact on the livelihoods of resettlers: When agricultural land acquisition happens, Vinh Hai commune has arranged a resettlement with area 318.84 hectares for 399 farmers who lost their land. However, land resettlement has worse quality. In Phuoc Dinh commune, the total area of agricultural land acquired is quite large, in which agricultural production land is revoked 448.50 hectares, forest land is 4.89 ha., aquaculture land is 109.85 ha. It is very difficult for the households who were compensated to find land for resettlement, therefore, career changing issues will be extremely difficult, especially for workers who are older, and have low levels of education. Among the households surveyed, the proportion of household having primary education in Vinh Hai commune is $45 \%$ and in Phuoc Dinh is $75 \%$. The two communes not yet headed up to the college level or higher. Of the 80 households eligible for the survey, the proportion of household employed in agriculture is $82.5 \%$ in Vinh Hai commune, and Phuoc Dinh commune is $45 \%$.

Since the vast majority of households live on agriculture production, their lives are seriously affected when land is acquired. Without any mechanisms and policies supporting, sooner or later in time, these households will also become poor and become a burden to the society.

The impact on income of the people whose land is acquired: Most farmers whose land is acquired whether residential or agricultural land will receive an amount of compensation. According to calculations in migration projects for resettlement, the amount of compensation and assistance is 1,408.764 billion dong, the number of households whose land is acquired is 1,435 , the average household has received nearly one billion currency compensation, and support and resettlement help transform careers and create stable life. With the relocation, the construction of housing is needed and the farmers have to spend money to build. However, the issue of using money to support career changing often produces negative issues, not used for the right purpose. This is the risk, and in many cases is the negative impact of land acquisition to sustainable livelihoods of farmers.

According to the survey results, about $50 \%$ of the households surveyed intend to use the money compensated to fund their children to school; $47.5 \%$ of the households surveyed intend to use this money to purchase luxury items. Only $15 \%$ of households intend to buy more land for production and 19\% of households invest in job transition training; $30 \%$ of households intend to use this money to invest in finding a new job (see Table 1 below). These result in the ability to quickly spend all the land acquisition compensation for some households and make dificulty for the local government to set up policies for people living there and the sustainable livelihoods of the people whose land is acquired will be affected. 
Table 1. Income of Agricultural Households at Ca Na (Thuan Nam) and Thanh Hai (Ninh Hai) (Unit: Billion Dong)

\begin{tabular}{lllll}
\hline TT & Criteria & Highest & Lowest & Medium \\
\hline & Average income of household surveyed & $2,000.00$ & -155.00 & 302.93 \\
1 & Income from handicraft & $1,000.00$ & -175.00 & 182.55 \\
2 & Income from livestock & 70.00 & -10.00 & .90 \\
3 & Income from seafood processing industry & $2,000.00$ & .00 & 105.35 \\
4 & Income from other production activities & 10.00 & .00 & .13 \\
\hline
\end{tabular}

Note: Source: From the survey of research group.

\section{People Whose Land Acquired to Build Two Nuclear Power Plants in Ninh Thuan}

From surveys and research experience of the countries having mechanism, policy support for the construction of nuclear power plants, we would like to suggest a number of mechanisms and policies to support and ensure sustainable livelihood for people living in the affected areas in Thuan Nam and Ninh Hai, Ninh Thuan as follows:

Mechanisms and policies on land compensation prices acquired to build two nuclear power plants in Thuan Nam and Ninh Hai. To ensure the livelihood of the people whose land has been acquired to build nuclear plants, the Government issued Decision 1504/QD-TTg dated August 28, 2013. However, in the Decision, the land compensation price according to the land price frame in Ninh Thuan province is very low; no discrimination and eliminating the land speculators and no compensation for the land rented for public benefits caused many questions and potential complaints from people whose land is acquired. In addition, the construction site of the nuclear power plants is located in the communes having difficult economic conditions, then their lives are more seriously affected than the other areas. From this situation, we propose:

Firstly, increasing by $25 \%$ in the price of land applied in compensation under Decision 1504/QD-TTg closing to the land use right price in the market;
Secondly, distinguishing clearly and properly who will receive compensation from land acquistion to remove land speculators. Accordingly, the portion of compensation will be paid directly to the persons who are entitled to use the land, who have the certificate to prove the legitimacy of their right to use the land, and who are living on the acquired land;

Thirdly, households and individuals leasing public land for agricultural production are also entitled to receive support as the cases stipulated in Clause 3, Article 35 of Decision 1504/QD-TTg. The supported amount is calculted by $80 \%$ of agricultural land price, $20 \%$ of the remaining land price is allowed to leave the local additional funds in the public interest.

With the proposes suggested above, the amount of money increase for the people whose land is acquired when prices rise $25 \%$ is 60.061 billion dong, the average household will receive 41.85 million. This is quite a large amount for households whose land is recovered. The amount added will significantly contribute to ensuring stable income and living standards of the people whose land is acquired in Phuoc Dinh and Vinh Hai.

Adjustment mechanisms and policies on compensation, support, and resettlement under Decision 1504/QD-TTg. Besides the unreasonable problems of land, the support for changing career under the Decision 1504/QD-TTg is also as low as two times of the price of agricultural land, while Decree 69/2009/ND-CP is from 1.5-5 times. The fuel 
assistance, textbooks, free school fees, contributions to building schools in the three years since the land acquisition for irrigation projects, and hydropower supported by the Decision 34/2010/QD-TTg dated August 4, 2010 were in effect, but not expressed in Decision 1054.

First, increasing support for career changing and job creation from two times to five times compared to the price of agricultural land-the maximum level stipulated in Decree 69/2009/ND-CP dated August 13, 2009 of the Government to ensure that the people whose land is acquired can change their job.

Second, supporting fuel for one year for households in Vinh Hai, Phuoc Dinh equivalent to three liters/person/month at the rate stipulated in Paragraph 5, Article 10 of Decision No. 34/2010/QD-TTg of the Prime Minister.

Third, additional support for mental damages to households whose land is acquired. The amount is 10 million/household, the total amount of support for 1,535 households whose land is acquired, including agricultural land and residential land, is 15.35 billion, on average per year is 5,117 billion.

Fourth, children from households whose land is acquired will recieve grants for textbooks, tuition fee exemption for one year, and money to build schools in three years. With nearly 2,000 pupils at the commune levels, total amount supporting is about three billion dong.

With the above suggestions, total grants raise up to 654.25 billion, which is also quite large fund to contribute to ensuring a sustainable livelihood for the people whose land is directly acquired.

Policy incentive allowances for civil servants and employees working in Thuan Nam and Ninh Hai. Thuan Nam and Ninh Hai, including Phuoc Dinh and Vinh Hai apply staff allowances under Decree 116/QD-TTg dated December 24, 2010. However, since rearranging objects and poor communes under the new criteria, both districts are not included in the district area, poor communes should not apply the preferential allowances. Especially since district establishment in Thuan Nam, the Government issued decision 466/QD-TTg supporting for officers work in the district; whereby officials and employees working in Thuan Nam will have living allowance initially, gasoline, and land. However, the life of officers and employees in the province still faces many difficulties. To attract civil servants working in the area, it would suggest:

First, applying the policy for attractive allowances and seniority allowances for officials and public servants, officers, professional soldiers, and defense employees working in Thuan Nam district and Vinh Hai commune, Ninh Hai district.

Incentive allowances are equal to $70 \%$ of their respective current monthly wage. Seniority allowances by .5 compared to the minimum wage are applied to people working full time for five years and under 10 years, with .7 for the actual work between full 10 years and under 15 years and for people working for 15 years or more. Officers, employees, officers, professional soldiers, and defense employees who work at Phuoc Dinh commune have attractive allowances equal to $100 \%$ of their respective current monthly salary.

Second, supporting petrol and land for officers, civil servants, professional soldier, and defense employees working in Thuan Nam district. The amount is 300,000 $\mathrm{VND} /$ person/month and 150 $\mathrm{m}^{2} /$ household.

With subsidies, the total amount supporting is 57.821 billion dong/year and 173.463 billion dong in three years (as shown in Table 2 below).

Policies and mechanisms to support the development and production transformation. Policies to support the restoration and protection of the coastal fores, create perimeter protection of power plants, agricultural activities, forestry, fisheries, and landscaping to attract tourism activities. Specifics:

(1) Increasing investment in afforestation rate in order to balance the investment plan under Decision 
Table 2. Summary of Resources to Support Implementation of the Specific Policy Mechanisms for Two Ninh Thuan Nam Hai Districts

\begin{tabular}{ll}
\hline Content & Total support (billion dong) \\
\hline Adjustment mechanisms and policies on land acquisition to build nuclear power plant & 72.974 \\
Adjustment mechanisms and policies to support the livelihood of farmers whose land is acquired & 654.250 \\
Support mechanisms and policies for personnel salary budget & 173.163 \\
Mechanisms and policies to support forestry development & 40.716 \\
Mechanisms and policies to support off-shore fishing, fishing conversion & 495.184 \\
Loan support on aquaculture, fish processing, seafood & 30.000 \\
Support livestock development, loans on cattle breeding & 14.400 \\
Support price of electricity for residents in two districts & 168.611 \\
Total & $16,320.058$ \\
\hline
\end{tabular}

Note: Source: Calculated by research group.

No. 60/2010/QD-TTg of September 30, 2010 from 15 million/ha. to 25 million/ha. Because, the actual costs have increased over time and conditions of the plantation in Ninh Thuan Nam Hai are very difficult because of the terrain, weather, and climate;

(2) Raising the level of protection contracts for protecting forests and special-use forests to households, individuals, and rural communities of the forest management units, from .2 million/ha. according to Decision No. 60/2010/QD-TTg of September 30, 2010 to .3 million/ha.;

(3) Increasing the amount of money for project management of protective and special-use forests, from $10 \%$ of the total investment of the State budget for the project, according to Decision No. 60/2010/QD-TTg of September 30, 2010 to $12 \%$.

With the policy mechanisms, the total investment is 1,590 hectares, balance for the planning of Thuan Nam and Ninh Hai District 2020 is 39.75 billion dong. The difference is due to changes in mechanism.

Policy supporting conversion of grounds: Establishing safety at sea corridor for nuclear power plants having narrow grounds must lead to change from inshore to offshore fishing.

To enforce that matter, it needs to support fishermen reformation on boat building in large capacity, training captain and the mechanic, the operating crew on boats and fishing access. Specifics:

(1) Supporting $100 \%$ loan interest rate for the first five years of boad building; $50 \%$ of the loan interest rate in the next five years, the interest rate applied $1.5 \% /$ year. Duration of the loan is 10 years. The maximum loan rates by $100 \%$ of ships, depending on the conditions of the borrower, with the evaluation of local governments and credit institutions;

(2) Supporting credit and the interest rate subsidy to buy fishing gear, the additional equipment on ships serving offshore fishing operations at the rate of $1.5 \% /$ year for five years;

(3) To support the fuel, with 50 million/year/vessel;

(4) To support the vocational training qualifications and meet the requirements of offshore fishing for the captain and the chief engineer; the support is 1.5 million/person; and execution time is to the end of 2018;

(5) To support $50 \%$ of hull insurance, accident insurance $100 \%$ for the crew, with 100 million/boat; total assistance on interest rates, insurance, training, support for activities of petroleum... offshore fishing is 495.184 billion as shown in Table 2 above. The funds supporting shipbuilding and other forms of 
assistance such as insurance, interest rate subsidy to buy fishing gear, fuel, equipment... shall be deducted from the central budget through interest subsidies of the State Bank for commercial banks.

Interest rate support policy on aquaculture, fish processing, seafood, and cattle breeding: These activities bring greater income for people in Ninh Hai and Thuan Nam districts and also develop potentially. Therefore, there is need to expand these activities by various measures, including financial support through interest rate support. Specifically: Interest subsidy and improve lending procedures for households in Thuan Nam and Ninh Hai for development of cattle breeding, aquaculture, and seafood processing; preferential rate of 3.0\%/year; support term interest rates from 1-2 years, depending on the duration of the production. Total support of 30 dong billion to support lending rates in aquaculture, fish processing, seafood and 14.4 billion to support the expansion of the interest rate raising cattle.

Policy supporting power prices for people living in two districts: Most countries with nuclear power plants have implemented policies to support the price of electricity. On the other hand, Thuan Nam and Ninh Hai districts are the revolutionary areas with many ethnic minorities and having difficulty in living conditions. With this context, the proposal is supported by $30 \%$ electricity price under the current electricity price of Vietnam Electricity for households in two districts. Power consumption support is calculated according to the average electricity consumption per capita according to the district and the actual electricity price on average.

\section{CONCLUSIONS}

Construction of nuclear power plant in Ninh Thuan Nam Hai, Ninh Thuan is the right decision. However, due to the characteristics of nuclear power plants, the construction will impact on the sustainable livelihoods of local people, hence it needs to have specific mechanisms and policies to support. If the mechanisms, specific policies are accepted and implemented, certainly sustainable livelihoods of the people of two districts of Ninh Thuan Nam Hai, Ninh Thuan province-the construction of nuclear power plants will be ensured, contributing to the sustainable development of agriculture and rural areas in particular, and of the two districts of Ninh Thuan province in general.

\section{References}

Krantz, L. 2001. The Sustainable Livelihood Approach to Poverty Reduction. Swedish International Deveplopment Agency (SIDA). Retrieved (http://www.sida.se).

Nguyen, V. S. 2013. “Sustainable Livelihoods Framework: A Comprehensive Analysis of the Development and Poverty Reduction." In Social Inequality in Vietnam and the Challenges to Reform Conference, edited by Philip.

Ravaliion, M. and D. van de Walle. 2008. Land in Transformation Period: Improvement and Poor Reduction in the Rural Vietnam. The Cultural Information Publisher.

The Government. 2009. Decision No. 443/QD-TTg Dated 04/04/2009 of the Prime Minister Regarding the Interest Rate Support to Organizations and Individuals Borrowing Medium Term Bank Loans to Implement New Investments to Develop Production-Business.

- 2013a. Decision 1504/QD-TTg on the Issuance of Compensation Policy, Migration Support and Resettlement Projects in Ninh Thuan Nuclear Power.

— 2013b. Decision No. 826/QD-TTg Dated 29/03/2013 of the Prime Minister on the Amendment and Supplement of Some Articles of Decision No. 2406/QD-TTg Dated 18/12/2011.

Vietnam Electricity Department. 2012. Project Management Board of Nuclear Power-A Summary Report on the Implementation of Nuclear Power Projects in Ninh Thuan.

\section{Bio}

Ngo Thi Phuong Thao, Ph.D., Faculty of Real Estate and Natural Resources Economics, The National Economics University, Vietnam; research fields: economics, land economics and management, real estate market and appraisal. 